\title{
Knowledge Management and Employee Efficiency in Deposit Money Banks in Port Harcourt, Nigeria
}

\author{
Binafeigha Mumere Sarah", Asawo Soye Peniel \\ Rivers State University of Science and Technology, Nigeria
}

Copyright $\mathrm{C} 2018$ by authors, all rights reserved. Authors agree that this article remains permanently open access under the terms of the Creative Commons Attribution License 4.0 International License

\begin{abstract}
This study examined the relationship between knowledge management and employee efficiency in deposit money banks in Port Harcourt, Nigeria. From a study population of 680 bank employees in Port Harcourt, the sample size of 248 respondents was determined using the sample size determination table. Adopting the cross-sectional survey design, the obtained data was analysed at the primary and secondary levels with the mean score and Pearson's Product Moment Correlation Co-efficient respectively. Results from the analysis revealed that there is a significant and positive relationship between the four dimensions of knowledge management (i.e. knowledge identification, acquisition, sharing, and application) and employee efficiency. The study concluded that the knowledge asset of banks is an important predictors of their employees' efficiency. In view of this, the study recommends that banks should invest in enhancing their knowledge management practices so as to enhance the performance level of their employees with regards to their efficiency.
\end{abstract}

Keywords Knowledge Management, Knowledge Identification, Knowledge Acquisition, Knowledge Sharing, Knowledge Application, Efficiency

\section{Introduction}

Banks in Nigeria, like several organisations globally, are experiencing high and intense competitive pressure owing to changes in technology and globalisation thus forcing them to be more dynamic in their operations. Given this condition, it is necessary to state that firms that rank high and stand out in their respective industries are those with the ability to make the most of their knowledge assets, better and quicker than their rivals. This view is supported by Kinyua, Muathe, and Kilika, (2015: 432) that argue that management scholars (Sher and Lee, 2004; Wong and Aspinwall, 2006; Liu and Wei, 2009) "concur that competitive advantage in the 21 st century is linked to knowledge-based resources which provide heterogeneous capabilities thus giving each organisation its unique character". Clearly, knowledge contributes to performance hence a source for gaining competitive edge (Teece, 1998). Accordingly, knowledge is the principal force that determines and drives employees' ability to act intelligently (Wiig, 1997). In other words, when employees have more current and valuable knowledge in terms of their organisations' core activities, they are better equipped to make smarter decisions, which in turn causes them to perform better. Consequently, identifying, acquiring, sharing and applying knowledge have become increasingly valuable to organisational performance.

Thus, knowledge and the management of knowledge is today viewed as a vital facet for the performance of any organisation, which is why organisations that manage and share their knowledge effectively are more resourceful and perform better (Riege 2007). Scholars (Nevo et al. 2009; Huber 1991; Hinds and Pfeffer 2003; Alavi and Leidner 2001) have thus emphasized the need for knowledge management as a key determinant of organisational success. That is because knowledge management ensures that the exact knowledge gets to appropriate users in the right place where it is most needed and at the right time and format (Mäki, 2008).

Given that firms compete amongst themselves on the bases of their resources and capabilities, employees as part of the organisation's resources, are the most valuable asset any organisation can possess because their individual and collective expertise contribute greatly to the organisations core objective. More so, giving heightening business competition, organisations now pay more attention to employees' accomplishments, thus the need to better manage the workforce. According to Daft (2006) the importance of human resources have been recognized in management given that, among other things, the success or failure of any organisation depends significantly on the performance of the employees that constitutes the organisation's workforce, confirming Alo's (1999) view that competitive advantage can be mostly achieved and maintained through people. 
Besides other variables that predicts employee performance as evident in empirical studies, researchers and practitioners agree that knowledge management is currently one of the key elements that could enhance performance in this current era (Newman and Conrad 2000, Stankosky 2008 and Dahiya et al., 2012). Specifically, Uit Beijerse (1999) argues that one of the key benefits of knowledge management is improved efficiency. However, there is little evidence of empirical studies conducted in Nigeria on the effect of knowledge management on employees' efficiency. The post consolidation era of the Nigerian Banking Industry has gone through a lot of transformation in the management of their knowledge asset with the digitalisation of banking operations geared towards resource optimisation. But studies that have looked at the predictive nature of knowledge management on employees' efficiency as a key measure of performance in Nigeria appear scares. The purpose of this study is therefore to examine the relationship between the knowledge management dimensions of knowledge identification, acquisition, sharing, and application, and employee efficiency in deposit money banks in Port Harcourt, Nigeria.

The study therefore sought answers to the following research questions:

1. What is the relationship between Knowledge Identification and Employee Efficiency in Banks in Port Harcourt, Nigeria?

2. What is the relationship between Knowledge Acquisition and Employee Efficiency in Banks in Port Harcourt, Nigeria?

3. What is the relationship between Knowledge Sharing and Employee Efficiency in Banks in Port Harcourt, Nigeria?
4. What is the relationship between Knowledge Application and Employee Efficiency in Banks in Port Harcourt, Nigeria?

\section{Literature Review}

\subsection{Employee Efficiency}

The criterion variable in this study is employee efficiency, which is a measure of employee performance. Armstrong and Murlis (2004) opined that employee performance involves completing assigned task by individual or group of individuals in an organisation which according to Kenney et al. (1992) is measured against the performance standards set by the organisation. Various measures are taken into account when measuring performance such as productivity, efficiency, effectiveness, quality and profitability (Ahuja 2006). This study however focuses on efficiency and according to Burnes (2004), efficiency presents the level of different goals achievement within the limited available resources. Similarly, Mihaiu, Opreana and Cristescu (2010: 132) state that efficiency "can be achieved under the conditions of maximising the results of an action in relation to the resources used, and it is calculated by comparing the effects obtained in their efforts". An important point to note is that workers in the organisation must be aware of what they need to do so as to execute their duties successfully hence organisation need to outline and set out its employee performance expectations so that accomplishment can be accurately appraised periodically.

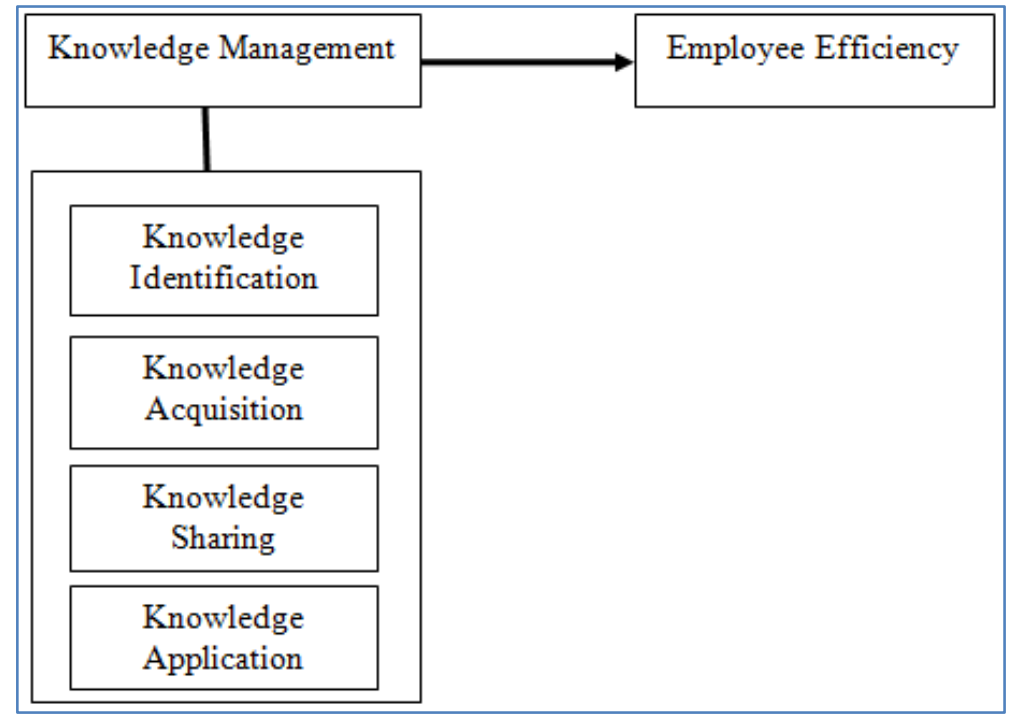

Source: Desk Research

Figure 1. Conceptual Framework of Knowledge Management and Employee Efficiency adapted from Yip et al. (2013) knowledge management processes framework. 
Efficiency is an indicator that is obtained by reporting the outcome effects to the efforts made (Mihaiu, Opreana and Cristescu, 2010: 136). Thus, efficiency in the work place refers to the time, money, and other resources it takes to accomplish assigned tasks as compared to the set standards determined by the employer. This suggests that efficient employees complete tasks in the least time possible with the least amount of resources possible by utilising certain time-saving strategies. Jayamaha and Mula (2011: 454) gave an operational definition of efficiency thus:

Efficiency consists of two main components; technical efficiency and allocative efficiency (Coelli, Rao et al. 1998). Generally, the term efficiency refers to technical efficiency. ...technical efficiency occurs if a firm obtains maximum output from a set of inputs. Allocative efficiency occurs when a firm chooses the optimal combination of inputs, given the level of prices and the production technology (Coelli, Rao et al. 1998; Rogers 1998). When a firm fails to choose the optimal combination of inputs at a given level prices, it is said to be allocatively inefficient.

Efficiency can therefore be viewed as measuring how much effort and/or expense is required for an employee to maximize productivity by, (1) being innovative, (2) generating creative solutions to cut costs, (3) minimising the number of errors made in production, or (4) increasing accuracy. Inefficient employees and managers take the longer road in executing their task. Most times, this is due to the fact that they probably lack the required knowledge or experience bottlenecks in knowledge flow and/or their inability to apply identified and acquired knowledge in solving actual problems.

\subsection{Knowledge Management}

Knowledge management has been widely analysed and discussed in the last decade in different fields and contexts (Lopez et al., 2004) resulting to the many-sided definitions of the concept. In an attempt to define the concept, Jennex (2007), describes it as the process of logically selecting suitable knowledge generated from previous experiences with the intension of applying such valuable knowledge in resolving present and potential drawbacks thus enhancing the organisation's effectiveness. It involves planning, organising, motivating, and controlling people, processes and procedures inside the organisation to make sure that its knowledge-related assets are enhanced and successfully utilized (King, 2009). Thus, knowledge management process is set in motion by the recognition and identification of the prevailing knowledge types existing within the organisation preceded by understanding how and where the knowledge resides (Little, 2010) and finally ensuring that the knowledge is well disseminated and effectively and efficiently applied in decision making. Similarly, Grey (1996) sees knowledge management as an assessment of intellectual assets that gives prominence to unique resources, critical functions and potential bottlenecks which may hinder knowledge flow to the point of use. Thus, it protects intellectual assets from obsolescence, seeks prospects of enhancing performance through adding intelligence, increasing value, and providing flexibility.

In addition, knowledge management is seen as a systematic and integrative process of harmonising an organisation's broad activities of acquiring, creating, storing, sharing, diffusing, developing, and deploying knowledge by individuals and groups seeking to achieve major organisational objectives (Rastogi, 2000). On the other hand, some other researchers perceive Knowledge Management as consisting of a variety of strategies and practices that are applied within the organisation, which allows acceptance and usage of expertise and knowledge that is either personified in the employee or rooted in organisations as processes or practices (Gupta and Sharma, 2004, Ferguson 2005, Serenko et al., 2010). Generally speaking therefore, knowledge management essentially is concerned with the process of identifying, acquiring, distributing and maintaining knowledge that is essential to improving performance in order to achieve the organisation's goals. In this regard, Ow et al. (2001) define Knowledge Management as a process of identifying, acquiring, applying, sharing, developing, creating, preserving and measuring knowledge in organisation

Radding (1998) posits that the application of knowledge management in organisations prevents knowledge loss, improves decision making, promotes adaptability, develops intellectual assets and enhances product and service deliveries. Knowledge management empowers employees through the processes of capturing information and creating knowledge (Grey, 1996) consequently increasing workers productivity level given the accessibility of knowledge by all employees (Pervaiz et al. 1999). Some of the benefits of knowledge management as outlined by Uit Beijerse (1999) include improved efficiency, competencies, market share, continuity, profitability, product growth, decision making, interaction and corporation.

\subsection{Knowledge Management Dimensions}

This study adapts Yip et al. (2013) framework of knowledge management, which is seen as a process with a 'start-off-point' - Knowledge Identification - and 'end-point' - Knowledge Application - and in between are Knowledge Acquisition and Knowledge Sharing comes to play. For this study, knowledge creation is embedded in knowledge identification while knowledge transfer is embedded in knowledge sharing.

\section{Knowledge Identification}

Knowledge identification is a part of a well-known 
knowledge management framework as outlined by Probst et al. (2000). It refers to recognising the set of knowledge required to support the entire business strategy, audit the existing organisation's knowledgebase, and transforming the current knowledgebase into a newer and more formidable knowledgebase thereby bridging knowledge gaps within the organisation (Gopal and Gagnon, 1995). It is the process of taking initiative to practically pinpoint valuable knowledge within the organisation. Additionally, it has to do with ascertaining what knowledge employees need to accomplish their assigned task successfully. The knowledge management framework indicates that the results or deliverables of knowledge identification equally facilitates as well as enhances preceding knowledge management practices. For the reason that knowledge identification heralds the other activities in the knowledge management processes, its role is significant for the successful implementation of knowledge management in the organisation giving that as soon as the appropriate valuable and required knowledge has been identified, it is only then that the knowledge can be acquired, shared and applied to real situations. Some researchers have identified knowledge mapping, network system, expertise transfer etc. as techniques used to identify valuable knowledge within and outside the organisation (Werler, 2001, Hinds and Pfeffer, 2003, Weber at el, 2007).

\section{Knowledge Acquisition}

Subsequent to the identification of relevant knowledge comes knowledge acquisition (i.e. creating, capturing and gathering of knowledge), which likewise, is an important process in knowledge management. Knowledge acquisition upgrades and reinforces the organisations knowledge pool in addition to bridging identified knowledge disparity that exist within the organisation. According to Zack (1999), this is doable either by way of generating new knowledge through internal sources such as day-to-day experiences, employee expertise or by means of obtaining worthwhile knowledge from external information sources and other organisations. When seeking for appropriate sources that are outside the organisation, it is rather likely that the knowledge obtained will be from those with core competencies and knowledgeable enough to offer consequential inputs that will in turn, enhance efficiency. The acquisition of knowledge ranges from reports, meetings, training, previous work experiences, workshops and seminars etc., to data pertaining to customers, industries, contenders, outsourcing, professionals, etc. According to Hong (1999), organisations transform information gathered from within and outside the organisation into its unique and new knowledge stoke through its process of learning by way of combining the information with ideas, skills, expertise from previous experiences and the organisations processes. Some other techniques for bringing relevant knowledge into the organisation as proposed by some other proponents include interviews, external experts, stakeholders, observation, education and training, etc. (Lettieri at. el, 2004). Bhatt (2000) state that organisations are currently leaning towards outsourcing and adapting knowledge to their own needs which, is a simpler way of acquiring knowledge giving that knowledge creation activity is perhaps problematic especially when organisations go through painstaking processes identifying and retrieving explicit or tacit knowledge that they are unaware of.

\section{Knowledge Sharing}

After the required knowledge has been identified, created and/or acquired, the next line of action is distribution of the valuable knowledge throughout the organisation. Schwartz (2006) defines knowledge sharing as the exchange of knowledge, and this happens between and among individuals, and within and among teams, organisational units, and organisations. Schwartz (2006) further states that this exchange between or within the various sub-sets of the organisation may be focused or unfocused. Knowledge sharing is an important activity that enhances an individual capability to retrieve new data and resources for the purpose of learning, problem solving, and self-improvement (Din and Haron, 2012). Knowledge sharing is a focal and important component of knowledge management practice because it is crucial to attaining success in the organisation (Ipe, 2003). Sharing of knowledge creates room for cross-fertilisation of ideas, experiences, and expertise thus creating new knowledge and upgrading the organisations knowledge base (Argote and Ingram, 2000; Cohen and Levinthal, 1990; Kogut and Zander, 1992). This also enables employees within the organisation to collaborate with one another thereby jointly resolving work related setbacks (Wang and Noe, 2010). Various scholars have used different terms such as knowledge transfer, knowledge exchange, etc. to denote the general process of spreading knowledge among employees within organisation. Irrespective of the term used in literature, the practice of knowledge sharing involves the distribution of vital codified information such as procedures, standards, etc. and personalized knowledge such as new ideas, valuable experiences etc. among employees at all levels and units throughout the organisation (Chen and Huang, 2009; Lin and Lee, 2005). This ensures that the correct knowledge required is available to the right employee and at the exact time it is required (Sohail and Daud, 2009, Nkoyo et al. 2011).

\section{Knowledge Application}

After knowledge has been identified, acquired and shared, the next key focal point is the application of knowledge to actual situations. Knowledge application refers to the process of actually using the current knowledge to resolve prevailing setbacks (Gold et al., 2001; Alavi and Tiwana, 2002). Likewise, "it is the process through which knowledge is directly applied to task 
performance or problem solving" (Kinyua, et al., 2015:435). Simply put, it means putting the knowledge to action. This is an important aspect of knowledge management process given that the organisation can benefit from the identified, acquired and shared knowledge only when it is applied to resolve problems or make decision as it pertains to the organisations operations. Accordingly, knowledge without application is still considered as information in the actual sense of it (Zack 1999). It is important to also state that some notable benefits accruable to effective knowledge application include cutting down on errors while executing assigned tasks, utilising the correct knowledge in the precise format, managing diverse resources and converting collective knowledge to the benefit of the organisations (Bhat, 2001; Huang and Li, 2009; Gold et al., 2001).

\subsection{Knowledge Management and Employee Performance}

Empirical studies have shown that various knowledge management dimensions have the ability to drive performance outcomes (Choi and Lee 2002; Dröge, Claycomb and Germain, 2003; Sabherwal and Sabherwal, 2005, Dahiya et al., 2012). Likewise, Boumarafi and Jabnoun (2008) examined the relationship between the organisations' performance and knowledge management and concluded that knowledge management enhances performance and that knowledge management dimensions significantly correlates with performance improvement. In affirmation, Becerra-Fernandez, et al (2004) posit that knowledge management has a direct impact on employee performance by causing workers to be more adaptable as they interact with one another thus causing an increase in the level of efficiency. Knowledge management contributes to the overall organisations' performance by way of boosting employee performance levels, influencing the core organisations abilities, fast-tracking the time the service/product gets to the end user and improving the quality of the service/product (Davenport and Prusak, 1998, Argote and Ingram, 2000). Becerra-Fernandez, et al (2004) came up with 3 levels of impact that knowledge management has on employee performance one of which is efficiency. Consequently, the following hypotheses were tested in the study:

$\mathrm{Ho}_{1}$ : There is no significant relationship between Knowledge Identification and Employee

Efficiency in Banks in Port Harcourt, Nigeria

$\mathrm{Ho}_{2}$ : There is no significant relationship between
Knowledge Acquisition and Employee Efficiency in Banks in Port Harcourt, Nigeria

$\mathrm{Ho}_{3}$ : There is no significant relationship between Knowledge sharing and Employee Efficiency in Banks in Port Harcourt, Nigeria

Ho4: There is no significant relationship between Knowledge Application and Employee

Efficiency in Banks in Port Harcourt, Nigeria

\section{Research Methodology}

According to Kombo and Tromp (2006), research design is described as a scheme, outline or plan that is used to generate answers to research problems and Ahaiuzu and Asawo (2016) state that it determines the kind of data to be collected and how they will be collected. In this study, the cross-sectional survey design was adopted. Giving that the study sought to investigate the association between knowledge management and employee efficiency in Banks in Port Harcourt, the population of the study comprised of 680 bank employees which was drawn from the selected five (5) commercial banks operating in Port Harcourt as shown in Table 1.

From a study population of 680 bank employees, a sample size of 248 respondents was determined using the Krejcie and Morgan (1970) sample determination table. At the point of distribution of the questionnaire, these 248 respondents were randomly selected. This study relied on primary data and in line with the position of Brannick and Roche (1997) that hold that questionnaires are effectual apparatus to obtain primary data because of its ability to measure the study variables, a structured questionnaire was developed, and copies personally administered to respondents within the sample through drop and pick-later method. Subsequently, the data collected were transformed into forms suitable for further analysis. Out of 248 copies of the questionnaire distributed, 70 copies representing approximately $28 \%$ were not returned. An additional 5 copies, representing approximately $2 \%$ were significantly damaged and thus not included for analysis. Thus, the total copies of questionnaire returned and fit for use for analysis were 173 copies representing approximately $70 \%$ response rate. To ascertain the goodness of measure for the study instrument, validity was achieved following the outline by Politt and Beck, (2006), by ensuring that the instrument was subjected to an in-depth review by experts in the field. Also, reliability analysis was done to ascertain the Cronbach alpha coefficients as shown in Table 2 
Table 1. Population of the Study

\begin{tabular}{ccccc}
\hline S/No & Name of Bank & No of Branches & $\begin{array}{c}\text { Average No of Staff Per } \\
\text { Branch }\end{array}$ & Population \\
\hline 1 & First Bank Plc & 5 & 23 & 115 \\
2 & UBA Plc & 5 & 20 & 100 \\
3 & Ecobank Nigeria Plc & 5 & 18 & 90 \\
4 & Sterling Bank Plc & 5 & 28 & 140 \\
5 & Guaranty Trust Bank Plc & 5 & 47 & 235 \\
& & & & $\mathbf{6 8 0}$ \\
\hline
\end{tabular}

Source: SPSS 20.0 Output based on field survey data

Table 2. Summary of Reliability Analysis:

\begin{tabular}{ccccc}
\hline Variables & Original No of Items & Initial Cronbach's Alpha & $\begin{array}{c}\text { No of final } \\
\text { Items }\end{array}$ & $\begin{array}{c}\text { Cronbach's } \\
\text { Alpha }\end{array}$ \\
\hline Independent Variables & & & & \\
Knowledge Identification & 5 & .653 & 4 & .828 \\
Knowledge Acquisition & 5 & .619 & 4 & .687 \\
Knowledge Sharing & 5 & .631 & 4 & .699 \\
Knowledge Application & 5 & .327 & 4 & .831 \\
Dependent Variables & & & 4 & .802 \\
Employee Efficiency & 5 & .636 & 5 & .744 \\
Employee Effectiveness & 5 & .744 & & \\
\hline
\end{tabular}

Source: SPSS 20.0 Output based on field survey data

For data analysis, univariate and bivariate analyses were done using descriptive statistics (Mean Score) and inferential statistics (Pearson's Product Moment Correlation coefficients) respectively, with the aid of the Statistical Package for Social Sciences (SPSS) version 20.0. The univariate analysis was done to ascertain the state of the individual study variables in the industry while the bivariate analysis was done to examine the direction, strength and association between the variables and to test the hypotheses.

\section{Used Method Limitation}

"The main problem with small studies is interpretation of results, in particular confidence intervals and p-values" (Hackshaw, 2008: 1141). Even though the data for this study was generated with the intent of explaining the predictive effect of knowledge management on employee performance in the population at the estimated 95\% interval margin, the 173 subject is relatively small and poses a limitation for generalization.

\section{Data Analysis, Results and Findings}

\section{Descriptive Statistics - Univariate Analysis}

Table 3 shows the Mean Scores and Standard Deviation values of the respective variables thus Knowledge Identification, $\mathrm{M}=4.22(\mathrm{SD}=.60)$, Knowledge Acquisition, $\mathrm{M}=4.21$ ( $\mathrm{SD}=.61)$, Knowledge Sharing $\mathrm{M}=$ $3.41(\mathrm{SD}=.68)$ and Knowledge Application $\mathrm{M}=3.41$ (SD $=1.16)$. The table showed scores that are well above the midpoint which indicate that the dependent and independent variables are highly apparent in the banking industry. Additionally, the table displays Skewness values of $-1.31,-1.07,-.54,-1.22,-1.11$ and -.58 for the respective variables which indicate that the data are normally distributed. This is because the values falls within -2 and +2 . 
Table 3. Summary of Descriptive Statistics

\begin{tabular}{ccccccc}
\hline Variables & N & Mini & Maxi & Mean & Std. Deviation & Skewness \\
\hline Independent Variables & 173 & 1 & 5 & 4.22 & 0.60 & -1.31 \\
Knowledge Identification & 173 & 1 & 5 & 4.21 & 0.61 & -1.07 \\
Knowledge Acquisition & 173 & 1 & 5 & 3.99 & 0.68 & -.54 \\
Knowledge Sharing & 173 & 1 & 5 & 3.41 & 1.16 & -1.22 \\
Knowledge Application & 173 & 1 & 5 & 4.19 & 0.68 & -1.11 \\
Dependent Variable & & & & & \\
Employee Efficiency & & & &
\end{tabular}

Source: SPSS 20.0 Output based on field survey data

\section{Correlation Relationship - Bivariate Analysis and Testing of Hypotheses}

Correlation analysis is a statistical technique employed to describe the direction, significance, and intensity of the linear association amongst two variables (Pallant, 2007). A positive correlation depicts that when one variable changes in one direction, the associated variable also changes in the same direction while on the other hand, a negative correlation depicts that when one variable moves in one direction, the associated variable moves in the opposite direction (Pallant, 2007). According to Cohen (1988) correlation coefficient (r) can range from -1 to +1 . The prefix $(+,-)$ specifies the direction of the association (positive or negative), while the number denotes the strength of the association and the closer to 1, the stronger the relationship (Copper and Schindler, 2008); a correlation of zero (0) indicates that there is no relationship; a perfect positive correlation is 1 while a perfect negative correlation is -1 . Sequel to the purpose of the study, correlation analysis was employed to assess the extent, strength and direction of the relationship between the variables. Furthermore, the interpretation of the results from the analysis was based on the benchmark displayed in Table 4 as provided by Cohen (1988).

Table 4. Cohen's Guideline of Correlation Strength

\begin{tabular}{cc}
\hline R Values & $\begin{array}{c}\text { Strength of } \\
\text { Relationship }\end{array}$ \\
\hline$R=+0.10$ to 0.29 or $r=-0.10$ to -0.29 & Small \\
$R=+0.30$ to 0.49 or $r=-0.30$ to -0.49 & Medium \\
$R=+0.50$ to 1.0 or $r=-0.50$ to -0.1 .0 & Large \\
\hline
\end{tabular}

Source: Cohen (1988)

In addition, the decision rules for accepting or rejecting the hypotheses are:

Where $\mathrm{P}<0.05$ reject the null hypothesis

Where $\mathrm{P}>0.05$ accept the null hypothesis

\section{Association between Knowledge Identification and Employee Efficiency}

The results in Table 5 show that there is a statistically significant and positive relationship between Knowledge Identification and Employee Efficiency $(r=0.214, p=$
$0.005<0.05)$. The correlation coefficient represents a small correlation indicating slight relationship. Based on the level of significance, the null hypothesis which states that "There is no significant relationship between Knowledge Identification and Employee Efficiency" is rejected

Table 5. Correlation Relationship between Knowledge Identification and Employee Efficiency

\begin{tabular}{cccc}
\hline & & $\begin{array}{c}\text { Knowledge } \\
\text { Identification }\end{array}$ & $\begin{array}{c}\text { Employee } \\
\text { Efficiency }\end{array}$ \\
\hline Knowledge & Pearson Correlation & 1 & $.214^{* *}$ \\
Identification & Sig. (2-tailed) & & .005 \\
& $\mathrm{~N}$ & 173 & 173 \\
Employee & Pearson Correlation & $.214^{* *}$ & 1 \\
Efficiency & Sig. (2-tailed) & .005 & \\
& $\mathrm{~N}$ & 173 & 173 \\
\hline
\end{tabular}

**. Correlation is significant at the 0.01 level (2-tailed).

Source: SPSS 20.0 Output based on field survey data

\section{Association between Knowledge Acquisition and Employee Efficiency}

The results in Table 6 show that there is a statistically significant and positive relationship between Knowledge Acquisition and Employee Efficiency $(r=0.330, p=0.000$ $<0.05$ ). The correlation coefficient represents a medium level correlation indicating a considerable relationship. Based on the level of significance, the null hypothesis which states that "There is no significant relationship between Knowledge Acquisition and Employee Efficiency" is rejected

Table 6. Correlation Relationship between Knowledge Acquisition and Employee Efficiency

\begin{tabular}{lccc}
\hline & & $\begin{array}{c}\text { Knowledge } \\
\text { Acquisition }\end{array}$ & $\begin{array}{c}\text { Employee } \\
\text { Efficiency }\end{array}$ \\
\hline Knowledge & Pearson Correlation & 1 & $.330^{* *}$ \\
Acquisition & Sig. (2-tailed) & & .000 \\
& $\mathrm{~N}$ & 173 & 173 \\
& Pearson Correlation & $.330^{* *}$ & 1 \\
Employee & Sig. (2-tailed) & .000 & \\
Efficiency & $\mathrm{N}$ & 173 & 173 \\
\hline
\end{tabular}

**. Correlation is significant at the 0.01 level (2-tailed).

Source: SPSS 20.0 Output based on field survey data 
Association between Knowledge Sharing and Employee Efficiency

Table 7. Correlation Relationship between Knowledge Sharing and Employee Efficiency

\begin{tabular}{cccc}
\hline & & $\begin{array}{c}\text { Knowledge } \\
\text { Sharing }\end{array}$ & $\begin{array}{c}\text { Employee } \\
\text { Efficiency }\end{array}$ \\
\hline Knowledge & Pearson Correlation & 1 & $.406^{* *}$ \\
Sharing & Sig. (2-tailed) & & .000 \\
& $\mathrm{~N}$ & 173 & 173 \\
Employee & Pearson Correlation & $.406^{* *}$ & 1 \\
Efficiency & Sig. (2-tailed) & .000 & \\
& $\mathrm{~N}$ & 173 & 173 \\
\hline
\end{tabular}

**. Correlation is significant at the 0.01 level (2-tailed).

Source: SPSS 20.0 Output based on field survey data

The results in Table 7 show that there is a statistically significant and positive relationship between Knowledge Sharing and Employee Efficiency $(r=0.406, p=0.000<$ $0.05)$. The correlation coefficient signifies a medium level association thus demonstrating a considerable relationship. Based on the level of significance, the null hypothesis that state that "There is no significant relationship between Knowledge Sharing and Employee Effectiveness" is rejected

\section{Association between Knowledge Application and Employee Efficiency and Test of Hypothesis 4}

Table 8. Correlation Relationship between Knowledge Application and Employee Efficiency

\begin{tabular}{cccc}
\hline & & $\begin{array}{c}\text { Knowledge } \\
\text { Application }\end{array}$ & $\begin{array}{c}\text { Employee } \\
\text { Efficiency }\end{array}$ \\
\hline Knowledge & Pearson Correlation & 1 & $.216^{* *}$ \\
Application & Sig. (2-tailed) & & .004 \\
& $\mathrm{~N}$ & 173 & 173 \\
Employee & Pearson Correlation & $.216^{* *}$ & 1 \\
Efficiency & Sig. (2-tailed) & .004 & \\
& $\mathrm{~N}$ & 173 & 173 \\
\hline
\end{tabular}

**. Correlation is significant at the 0.01 level (2-tailed).

Source: SPSS 20.0 Output based on field survey data

The results in Table 8 reveal a statistically significant and positive relationship between Knowledge Application and Employee Efficiency $(r=0.216, p=0.004<0.05)$. The correlation coefficient represents a small level correlation indicating slight relationship. Based on the level of significance, the null hypothesis that state that "There is no significant relationship between Knowledge Sharing and Employee Effectiveness" is rejected.

\section{Discussion of Findings}

The relationship between knowledge identification and employee efficiency is found in this study to be positive and significant. In their study, Nnabuife and Ojukwu (2015), also revealed a positive association between knowledge identification and performance. Consequently organisations need to manage their knowledge identification processes excellently by mapping its knowledge assets effectively in order to improve performance. In support of this, Probst (1998) explains that most large organisation lose track of their knowledge assets which consequently lead to poor performance and redundant activities. It is therefore logical to state that lack of relevant knowledge is detrimental to employee performance and ultimately affects overall organisational outcomes. Thus organisations need to identify knowledge gaps in critical areas and provide the knowledge and skills required to enhance employees' efficiency. The awareness of available knowledge and skills both within and outside the organisations is very important (Probst, 1998). Therefore management should recognize the strength and weaknesses of their employees and try to enhance the employees' knowledge and abilities with required knowledge in the organisations (Afraze, 2005).

Also, this study also found that the association between knowledge acquisition and employees efficiency is positive and significant. This again corroborates the outcome of the study of Nnabuife and Ojukwu (2015) that showed that knowledge acquisition is significantly and positively associated with performance. These findings supports the fact that knowledge acquisition is a prerequisite for better employee decision making thus influencing other activities in the organisation (Lyles and Salk 1996). Similarly, Gholami et al. (2013) also concur that the organisation need to acquire knowledge to enhance strategic decisions, thus resulting in higher level of productivity, employee performance, innovation, work relationships, and customer satisfaction.

Again, the outcome of this study shows that the relationship between knowledge sharing and employee efficiency is positive and significant. Kuzu and Ozilhan (2014) conducted a study on the effect of employee relationships and knowledge sharing to employee performance and the results from the analysis affirms that knowledge sharing have a mid-level positive association with employee performance and explains $35 \%$ of employee performance. Also, Chong et al. (2011) infer that knowledge sharing process such as speed to transfer explicit knowledge and reliable transfer of tacit knowledge have positive influence on performance. Knowledge should be treated as a key economic resource thus the continuous dissemination of new and relevant information to key individuals and knowledge seekers within organisations is a prerequisite for increased performance level (Parasuraman et al., 1994; Wagner, 2006).

Finally, this study revealed a positive and significant association between knowledge application and employee performance. This findings supports Palanisamy's (2008) view that higher performance level is dependent on application of individual knowledge. Specifically, Daveport and Pursak (1998) argue that knowledge application helps organizations improve their efficiency 
and reduce costs. This is very important because an organisation can maximise profit either by increasing revenue or reducing cost.

\section{Conclusions and Recommendations}

Knowledge is critical in today's global economy because it is the key element to competitive viability in today's business environment. For this reason, knowledge needs to be managed effectively in order to compete successfully in the current business environment which is much more demanding given the advancement in technology and globalisation. This is especially true for the banking industry. For, according to (Kinyua et al., 2015:433):

Shih, Chang and Lin (2010) observed that banking is a typical knowledge-intensive industry that involves activities of knowledge exchange (service) rather than exchange of goods. Therefore, managing knowledge has become as important to Commercial Banks as it is for other knowledge based organisations. As noted by Rono (2011), KM is indispensable in the banking industry because competition and most of the work in the industry are knowledge-based. Moreover, the last open frontier for banks to create competitive advantage may reside in their ability to leverage knowledge, since banking is not just a business of handling money but also a business that is driven and sustained by information.

Following the research questions the study sought to answer, which led to the findings in this research, the study concludes that improvement in knowledge identification, acquisition, sharing and application, all of which are dimensions of knowledge management, will bring about an improvement of employees' efficiency by way of resource optimisation in the in bank operations.

From the findings and conclusion, the study makes the following recommendations that:

1. Bank should establish systems for discovering and locating valuable knowledge as this would bring to limelight untapped resources that could enhance employee efficiency.

2. Management of banks should endeavour to bridge the knowledge gap within the organisation by filling the void with required knowledge as this will avail employees with relevant information.

3. Management of banks should imbibe knowledge sharing culture among employee within the organisation so that employees can share what they know with others.

4. Management of banks should ensure that the identified, acquired and shared knowledge is applied to real life situations to solve problems as this will enable employees do better job of achieving valuable outcome with fewer resources.

\section{REFERENCES}

[1] Ahiauzu, A. I. \& Asawo S. P. (2016). Advanced Social Research Methods.Port Harcourt: CIMRAT.

[2] Ahuja, K. (2006). Personnel Management (3rd Ed). New Delhi, India: Kalyani publishers.

[3] Alavi, M, \& Leidner, D. E (2001). Knowledge management and knowledge management systems: Conceptual foundations and research issues. MIS Quarterly, 25 (1), 107-136.

[4] Alavi, M., \& Tiwana, A. (2002). Knowledge integration in virtual teams: The potential role of KMS. Journal of the American Society for Information Science and Technology, 53 (12), 1029-1037.

[5] Alo, O. (1999). Human Resource Management in Nigeria. Lagos: Business and Institutional Support Associates.

[6] Argote, L., \& Ingram, P. (2000). Knowledge transfer: A basis for competitive advantage in firms. Organisational Behavior and Human Decision Processes, 82, 150-169.

[7] Armstrong, M., \& Murlis, H. (2004). Reward Management: $A$ handbook of remuneration strategy and practice. London: Kogan Page Publishers.

[8] Bhatt, G. D. (2000). Organising knowledge in the knowledge development cycle. Journal of Knowledge Management, 4 (1), 15-26.

[9] Boumarafi, B., \& Jabnoun, N. (2008). Knowledge management and performance in UAE business organisations. Knowledge Management Research and Practice, 6 (3), 233-238.

[10] Brannick, T. \& Roche, W (1997). Business Research Methods: Strategies, Techniques and Sources. Dublin: Oak Tree Press.

[11] Burnes, B. (2004). Emergent change and planned changecompetitors or allies? The case of XYZ construction. International Journal of Operations \& Production Management, 24 (9), 886-902.

[12] Chen, C. J., \& Huang, J. W. (2009). Strategic human resource practices and innovation performance: The mediating role of knowledge management capacity. Journal of Business Research, 62 (1), 104-114.

[13] Cohen, J. (1988). Statistical Power Analysis for the Behavioral Sciences. Hillsdale: Kawrence Erlbaum Associates.

[14] Cohen, W. M., \& Levinthal, D. A. (1990). Absorptive capacity: A new perspective on learning and innovation. Administrative Science Quarterly, (35), 128-153.

[15] Cronbach, L. J. (1951). Coefficient alpha and the internal structure of tests. Psychometrika, 16 (3), 297-334.

[16] Daft, R. (2006). Organisation Theory and Design. Boston: Cengage Learning.

[17] Dahiya, D., Gupta, M., \& Jain, P. (2012). Enterprise 
knowledge management system: A multi agent perspective. Information Systems, Technology and Management. 2 (7), 271-281.

[18] Davenport, T. H., \& Prusak, L. (1998). Working Knowledge: How Organisations Manage What They Know. Yale: Harvard Business Press.

[19] Dröge, C., Claycomb, C., \& Germain, R. (2003). Does knowledge mediate the effect of context on performance? Some initial evidence. Decision Sciences, 34 (3), 541-568.

[20] Gholami, M. H., Asli, M. N., Nazari-Shirkouhi, S., \& Noruzy, A. (2013). Investigating the influence of knowledge management practices on organisational performance: An empirical study. Acta Polytechnica Hungarica, 10 (2), 205-216.

[21] Gold, A. H., \& Arvind Malhotra, A. H. S. (2001). Knowledge management: An organisational capabilities perspective. Journal of Management Information Systems, 18 (1), 185-214.

[22] Gopal, C., \& Gagnon, J. (1995). Knowledge, information, learning and the IS manager. Computerworld, 29 (25), 1-7.

[23] Grey, D. (1996). What is knowledge management? In The Knowledge Management Forum. http://km-forum.org/what is.htm. Accessed October 2016

[24] Gupta, J. N., \& Sharma, S. K. (2004). Creating knowledge based organisations. Igi Global, 10 (1), 84-102.

[25] Hackshaw, A. (2008). Small studies: Strengths and limitations. European Respiratory Journal 32 (5), 11411143.

[26] Hinds, P. J., \& Pfeffer, J. (2003). Why organisations don't know what they know: Cognitive and motivational factors affecting the transfer of expertise. Sharing expertise: Beyond Knowledge Management, 10 (8), 3-26.

[27] Huber, G. P. (1991). Organisational learning: The contributing processes and the literatures. Organisation Science, 2 (1), 88-115.

[28] Ipe, M. (2003). Knowledge sharing in organisations: A conceptual framework. Human Resource Development Review, 2 (4), 337-359.

[29] Jayamaha, A. \& Mula, J. M. (2011). Productivity and efficiency measurement techniques: identifying the efficacy of techniques for financial institutions in developing countries. Journal of Emerging Trends in Economics and Management Sciences (JETEMS), 2 (5), 454-460. Available from:

https://www.researchgate.net/publication/233727036 Prod uctivity_and_Efficiency_Measurement_Techniques_Identi fying the Efficacy_of_Techniques_for_Financial_Instituti ons_in_Developing_Countries [accessed Jul 02 2018].

[30] Jennex, M. E. (2007). Knowledge Management in Modern Organisations. Hershey, Pennsylvania: Idea Group Publishing.

[31] King, W. R. (2009). Knowledge Management and Organisational Learning. New York: Springer.

[32] Kinyua, G. M. Muathe, S. M. A. \& Kilika, J. M. (2015). Effect of knowledge conversion and knowledge application on performance of commercial banks in Kenya.
International Journal of Education and Research, 3 (10), 431-444.

[33] Kogut, B., \& Zander, U. (1992). Knowledge of the firm, combinative capabilities, and the replication of technology. Organisation science, 3 (3), 383-397.

[34] Kombo, D. K., \& Tromp, D. L. (2006). Proposal and Thesis Writing: An Introduction. Nairobi: Paulines Publications Africa.

[35] Krejcie, R. V., \& Morgan, D. W. (1970). Determining sample size for research activities. Educational and Psychological Measurement, 30 (3), 607-610.

[36] Kuzu, Ö. H., \& Ozilhan, D. (2014). The effect of employee relationships and knowledge sharing on employees' performance: An empirical research on service industry. Procedia-Social and Behavioral Sciences, 109 (10), 1370-1374.

[37] Lettieri, E., Borga, F., \& Savoldelli, A. (2004). Knowledge management in non-profit organisations. Journal of Knowledge Management, 8 (6), 16-30.

[38] Lin, H. F., \& Lee, G. G. (2005). Impact of organisational learning and knowledge management factors on e-business adoption. Management Decision, 43 (2), 171-188.

[39] Little, T. (2010). Understanding knowledge management: Developing a foundation for future advising practices. Retrieved from NACADA Clearinghouse of Academic Advising Resources Web site: https://www. nacada. ksu. edu/Resources/Clearinghouse/View-Articles/Knowledge-m anagement. Accessed. October 2016.

[40] Lyles, M. A., \& Salk, J. E. (1996). Knowledge acquisition from foreign parents in international joint ventures: An empirical examination in the Hungarian context. Journal of International Business Studies, 27 (5), 877-903.

[41] Mäki, E. (2008). Exploring and exploiting knowledge: Research on knowledge processes in knowledge-intensive organisations. PhD Thesis. Helsinki University of Technology. Unpublished.

[42] Mihaiu, D. M., Opreana, A. \& Cristescu, M. P. (2010). Efficiency, effectiveness and performance of the public sector. Romanian Journal of Economic Forecasting, 4, 132-147.

[43] Nevo, D., Benbasat, I., \& Wand, Y. (2009). Who knows what? MIT Sloan Management. 54 (4), 31-36.

[44] Nevo, D., Benbasat, I., \& Wand, Y. (2012). The knowledge demands of expertise seekers in two different contexts: Knowledge allocation versus knowledge retrieval. Decision Support Systems, 53 (3), 482-489.

[45] Newman, B. D. \& Conrad, K. W. (2000). A framework for characterizing knowledge management methods, practices, and technologies. In Reimer, U. (Ed.). Proceedings of the Third International Conference on Practical Aspects of Knowledge Management (PAKM). Basel, Switzerland, 3031.

[46] Nnabuife, E. K., \& Ojukwu, H. S. Knowledge Management and organisational performance in selected commercial banks in Awka, Anambra State, Nigeria. Journal of Business and Management, 17 (8), 25-37. 
[47] Palanisamy, R. (2008). Organisational culture and knowledge management in ERP implementation: An empirical study. Journal of Computer Information Systems, 48 (2), 100-120.

[48] Pallant, J. (2007). SPSS Survival Manual: A step-by-step Guide to Data Analysis using SPSS Version 15. Nova Iorque: McGraw Hill.

[49] Parasuraman, A., Zeithaml, V. A., \& Berry, L. L. (1994). Reassessment of expectations as a comparison standard in measuring service quality: Implications for further research The Journal of Marketing, 58 (1), 111-124.

[50] Pervaiz, A. P. K., Lim, K. K., \& Zairi, M. (1999). Measurement practice for knowledge management. Journal of Workplace Learning, 11 (8), 304-311.

[51] Politt, D. F., \& Beck, C. T. (2006). The content validity index: Are you sure you know what's being reported? Critique and recommendations. Research in Nursing \& Health, 29 (5), 489-497.

[52] Probst, G., J., (1998). Practical Knowledge Management: A Model that Works. Massachusetts: Prism-Cambridge.

[53] Probst, G., Raub, S. \& Romhardt, K. (2000). Managing Knowledge: Building Blocks for Success. Chichester: John Wiley and Sons Ltd.

[54] Radding, A. (1998). Knowledge management: Succeeding in the information-based global economy. Computer Technology Research Corp. 59 (2), 51-70.

[55] Riege, A. (2007). Actions to overcome knowledge transfer barriers in MNCs. Journal of Knowledge Management, 11 (1), 48-67.

[56] Schwartz, D. G. (2006). Encyclopedia of Knowledge Management, IGI Global. [electronic], http://library.books 24x7.com/toc.asp?bookid=14700.
[57] Serenko, A., Bontis, N., Booker, L., Sadeddin, K., \& Hardie, T. (2010). A scientometric analysis of knowledge management and intellectual capital academic literature. Journal of Knowledge Management, 14 (1), 3-23.

[58] Sohail, M. S., \& Daud, S. (2009). Knowledge sharing in higher education institutions: Perspectives from Malaysia. The Journal of Information and Knowledge Management Systems, 39 (2), 125-142.

[59] Stankosky, M. (2008). Keynote Address to ICICKM. Proceedings of International Conference on Intellectual Capital, Knowledge Management (ICICKM) And Organisational Learning. New York: New York Institute of Technology.

[60] Teece, D. J. (1998). Capturing value from knowledge assets: The new economy, markets for know-how, and intangible assets. California Management Review, 40 (3), 55-79.

[61] Uit Beijerse, R. P. (1999). Questions in knowledge management: defining and conceptualising a phenomenon. Journal of knowledge Management, 3 (2), 94-110.

[62] Wang, S., \& Noe, R. A. (2010). Knowledge sharing: A review and directions for future research. Human Resource Management Review, 20 (6), 115-131.

[63] Wiig, K. M. (1997). Integrating intellectual capital and knowledge management. Long Range Planning, 30 (3), 399-405.

[64] Yip, M. W., Ng, H. H., Din, S., \& Bakar, N. A. (2013) Knowledge management model for modern retail business: A conceptual framework. Synthesis, International Scholarly and Scientific Research \& Innovation, 7 (9), 11414- 16676.

[65] Zack, M. H. (1999). Developing a knowledge strategy. California Management Review, 41 (3), 125-145. 